\title{
The Effect of Defasciculating Doses of Pancuronium and Atracurium on Succinylcholine Neuromuscular Blockade
}

\author{
Cyrus Motamed $^{1, *} ;$ Duvaldestin Philippe $^{2}$ \\ ${ }^{1}$ Department of Anesthesia, Gustave Roussy Institute, Rue Camille Desmoulins 94080 Villejuif, France University of Paris 11, Paris, France \\ ${ }^{2}$ Department of Anesthesia, Hospital Henri Mondor, Avenue de Lattre de Tassigny 94010 Créteil, France University of Paris 12, Paris, France \\ *Corresponding author:Motamed Cyrus, Department of Anesthesia, Gustave Roussy Institute, Rue Camille Desmoulins 94080 Villejuif, France University of Paris 11, Paris, France. Tel: \\ +33-142114436 Fax:+33-142115209, E-mail: motamed@igr.fr
}

Received: February 24, 2014; Revised: April 7, 2014; Accepted: April 28, 2014

Background: A defasciculating dose of non-depolarizing muscle relaxant administered prior succinylcholine decrease its side effects including fasciculations and postoperative myalgias; however it is believed that the dosage of succinylcholine should be increased when such a pre-treatment is used.

Objectives: We hypothesized that a defasciculating dose of pancuronium as a pre-treatment could prolong its duration of effect.

Patients and Methods: Forty patients scheduled for elective orthopaedic surgery were consecutively assigned into 5 groups, a first group without pre-treatment (succinylcholine $1 \mathrm{mg} / \mathrm{kg}$ ) and 4 subsequent groups of pretreatment with atracurium $0.05 \mathrm{mg} / \mathrm{kg}+$ succinylcholine 1 or $1.5 \mathrm{mg} / \mathrm{kg}$ and pancuronium $7.5 \mu \mathrm{g} / \mathrm{kg}$ + succinylcholine $1 \mathrm{and} 1.5 \mathrm{mg} / \mathrm{kg}$. The muscle relaxant effect of succinylcholine was assessed with a force transducer using train of four stimulations every 12 seconds. Kruskall Wallis Anova test was used to compare results.

Results: The duration of succinylcholine induced paralysis $(1$ and $1.5 \mathrm{mg} / \mathrm{kg}$ ) was significantly prolonged with pre-treatment with pancuronium but succinylcholine $1 \mathrm{mg} / \mathrm{kg}$ did not reached maximum blockade after pre-treatment with atracurium. After pancuronium, full recovery after succinylcholine 1.5 and $1 \mathrm{mg} / \mathrm{kg}$ occurred respectively after 18 and 15 minutes. $\mathrm{P}<0.05 \mathrm{vs} .12$ minutes for succinylcholine $1 \mathrm{mg} / \mathrm{kg}$ alone.

Conclusions: This study highlights potentiation effect of a defasciculating dose of pancuronium on succinylcholine paralysis suggesting the lack of justification to increase succinylcholine dosage.

Keywords: Succinylcholine; Atracurium; Pancuronium

\section{Background}

Succinylcholine is used mainly used to facilitate tracheal intubation in emergency procedures but also in elective surgery, however because of multiple side effects including fasciculations muscle damage and late postoperative myalgia, a small dose of non-depolarising muscle relaxants (NDMR) may be used to decrease these side effects (1-6). Nearly all of NMDR might be used $(7,8)$, however magnesium sulphate is also reported to be efficient for this purpose (9). In addition, it's generally believed that the dose of Succinylcholine should be enhanced because of receptor competition with the NMDR (10-13).

\section{Objectives}

A defasciculating dose of Pancuronium might have different pharmacokinetic profile, because of serum anticholinesterase activity $(14,15)$. In previous works we investigated different effect of low dose of pancuronium on mivacurium pharmacodynamics, suggesting that the potentiation of mivacurium effect would mostly be the result of the anti-cholinesterase activity of a low dose of pancuronium although a receptors competitive ac- tion cannot be totally excluded (16-18). Succinylcholine, like mivacurium is eliminated by plasma cholinesterase (BChe) (19, 20), therefore we hypothesized the same pharmacokinetic effect of low dose of pancuronium (18) could enhance the duration of neuromuscular blockade of succinylcholine.

\section{Patients and Methods}

After ethical committee approval and informed consent 40 consecutive patients ASA I-III scheduled for elective orthopaedic surgery (bone marrow grafting of hip osteonecrosis) were assigned into 5 groups successively $(n=8$ per group). The study was prospective open labelled. Exclusion criteria were age less than 18 or more than 90 year, possible difficult airway, oesophageal reflux and hiatal hernia, allergy to muscle relaxants, renal insufficiency and Body Mass Index (BMI) higher than 33 and a proven history of deficit in cholinesterase activity. After the insertion of IV line, and standard operating room monitoring and pre-oxygenation, the following anaesthetic sequence was used for each group:

Copyright (C) 2014, Iranian Society of Regional Anesthesia and Pain Medicine (ISRAPM); Published by Kowsar. This is an open-access article distributed under the terms of the Creative Commons Attribution-NonCommercial 4.0 International License which permits copy and redistribute the material just in noncommercial usages, provided the original work is properly cited. 
- Group sux 1: sufentanil 5-15 $\mu \mathrm{g}+$ followed 2 minutes later by propofol 2-3 mg/kg followed by succinylcholine, $1 \mathrm{mg} / \mathrm{kg}$

- Group sux 1: sufentanil 5-15 $\mu \mathrm{g}+$ pancuronium $7.5 \mu \mathrm{g} / \mathrm{kg}$ followed 2 minutes later by propofol $2-3 \mathrm{mg} / \mathrm{kg}$ followed by succinylcholine, $1 \mathrm{mg} / \mathrm{kg}$

- Group sux 1.5: sufentanil 5-15 $\mu \mathrm{g}+$ pancuronium $7.5 \mu \mathrm{g} /$ $\mathrm{kg}$ followed 2 minutes later by propofol $2-3 \mathrm{mg} / \mathrm{kg}$ followed by succinylcholine, $1.5 \mathrm{mg} / \mathrm{kg}$

- Group Atra sux 1: sufentanil 5-15 $\mu$ g + atracurium 0.05 $\mathrm{mg} / \mathrm{kg}$ followed 2 minutes later by propofol 2-3 mg/kg followed by succinylcholine, $1 \mathrm{mg} / \mathrm{kg}$

- Group Atra sux 1.5: sufentanil 5-15 $\mu \mathrm{g}+$ atracurium 0.05 $\mathrm{mg} / \mathrm{kg}$ followed 2 minutes later by propofol 2-3 $\mathrm{mg} / \mathrm{kg}$ followed by succinylcholine, $1.5 \mathrm{mg} / \mathrm{kg}$

After the injection the non-depolarizing muscle relaxant (NDMR), any complaint in relation to their side effects (weakness, blurred vision difficulty in breathing or swallowing, desaturation) was noted.

Monitoring neuromuscular blockade was performed by a force transducer with a $300 \mathrm{~g}$ preload attached to a Gould $₫$ monitor, and train of four stimulation every 12 second yielded by a classic nerve stimulator on the adductor pollicis muscle (ulnar nerve). Tracheal intubation was performed when maximum succinylcholine neuromuscular blockade at the adductor pollicis was reached. Anesthesia was maintained with isoflurane 1
$\mathrm{MAC} /$ and $\mathrm{O}_{2}$ /air mixture and boluses of sufentanyl 5-10 $\mu \mathrm{g}$ as necessary.

\subsection{Statistical Analysis}

The sample size was designed to obtain a mean difference in full recovery of neuromuscular blockade of $3 \mathrm{~min}$ utes $(30 \%)$ with a standard deviation of 3 minutes a power of $80 \%$ and a confidence interval of $95 \%$. Kruskall Wallis ANOVA was used to compare results. A p value of less than 0.05 was considered to be statistically significant. Sys-Stat V10 for windows (IL, USA) was used for data analysis.

\section{Results}

The mean age of patients was of $59 \pm 12$ year with a mean weight of $75 \pm 23 \mathrm{~kg}$ and the mean height $167 \pm 11 \mathrm{~cm}$, no statistical difference was found between groups in demographic characteristics. No side effects occurred after the injection of pancuronium or atracurium.

Maximum blockade reached 100\% except in Atra sux 1 group (95\%).

The mean duration of Succinylcholine neuromuscular blockade $(1 \mathrm{mg} / \mathrm{kg}$ and $1,5 \mathrm{mg} / \mathrm{kg}$ ) was significantly prolonged when it was preceded by administration of low dose pancuronium and shortened when preceded by low dose atracurium in comparison with Succinylcholine $1 \mathrm{mg} / \mathrm{kg}$ alone $(\mathrm{P}<0.05)$ (Table 1$)$.

Table 1. Neuromuscular Characteristics of Different Combinations

\begin{tabular}{|c|c|c|c|c|c|}
\hline & $\mathbf{E} \operatorname{Max}^{\mathbf{a}}, \%$ & $\mathrm{~T} 70^{\mathrm{b}}$, Min & T $90^{b}$, Min & $\mathbf{T}_{100}{ }^{b}$, Min & Significance \\
\hline Atra sux 1 & 95 & $4.8(3.3-7.4)$ & $6.0(4-8.5)$ & $7.1(4.8-9)$ & $\mathrm{P}<0.05$ vs sux 1 \\
\hline Panc sux 1 & 100 & $12.2(7-21.5)$ & $14.3(8.8-23.7)$ & $15.8(11.3-26)$ & $\mathrm{P}<0.05$ vs sux1 \\
\hline Sux 1 & 100 & $9.1(5.8-13.2)$ & $11.5(6.8-15.7)$ & $12.4(9.1-16.9)$ & - \\
\hline Panc sux 1.5 & 100 & $13.3(8.2-20.8)$ & $15.8(10.7-24.1)$ & $18.2(12.5-28.7)$ & $\mathrm{P}<0.05$ vs sux 1 \\
\hline Atra sux 1.5 & 100 & $8.6(4.7-12.3)$ & $10.4(5.8-10.5)$ & $12.6(7.2-16)$ & $\mathrm{P}<0.05$ vs panc sux 1.5 \\
\hline
\end{tabular}

a Emax, maximum blockade.

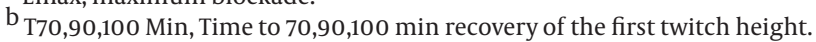

\section{Discussion}

This study shows that low dose of pancuronium prolongs the duration of action of Succinylcholine induced paralysis whereas atracurium reduces it, therefore increasing the dose of succinylcholine is not necessary in case of pancuronium pre-treatment. Traditionally the administration of a very low dose of NDMR is used to prevent succinylcholine induced side effects (mostly fasciculations and post-operative myalgias) (21), however the dose of sucinylcholine should be increased to obtain satisfactory neuromuscular paralysis and or intubation conditions described in several investigations $(10,12,22)$ this was demonstrated also in the present study with atracurium followed by succinylcholine $1 \mathrm{mg} / \mathrm{kg}$ since the maximum neuromuscular effect was of $95 \%$ in comparison to other combinations or alone. Nevertheless, despite multiple studies considering side effects of pretreatment very few investigated the duration of induced paralysis after such combinations.

As previously described with mivacurium, the potentiation of succinylcholine by pancuronium might be explained by the reduced hydrolysis of succinylcholine due to Bche inhibition (18). Although clear relationship between a decrease in Bche and a prolongation of effect of mivacurium could not be demonstrated (18).

We used the higher dose of pancuronium suggested for pre-treatment (21) to fulfill the purpose of the study in 
order to yield a decrease in cholinesterase activity, however our timing of the propofol injection (2 minutes after injection of low dose of pancuronium or atracurium), avoided the occurrence of side effects including blurred vision, diplopia, heavy eyelids, weakness, difficulty in breathing and swallowing or desaturation.

This investigation was open labelled, and not randomized since our primary endpoint was objective assessment of dose-effect relationship in clinical practice, we also did not measured the Bche after administration of pancuronium but in accordance to our previous dose-response investigations with intubating and maintenance doses we assumed Bche would significantly decrease despite remaining within clinical range (18). In addition the sample size was not chosen to evaluate the side effect of succinylcholine but only to prove an increase in the duration of paralysis. This study confirms the result of a previous investigation using higher dose of NDMR for pre-treatment (17).

Low dose of NDMR before succinylcholine is considered to be safe provided accurate dosing and timing however we suggest to consider also the type of NDMR as pancuronium enhances the effect of succinylcholine and atracurium reduces it, therefore increasing the dose of succinylcholine is not justified when pancuronium is used as a pre-treatment.

\section{Author's Contributions}

Cyrus Motamed and Philippe Duvaldestin designed performed the study and wrote the manuscript.

\section{Funding/Support}

Funding was from the department of anesthesiology Hospital Henri Mondor Créteil France.

\section{References}

1. Fagiano G, Vignotto F, Galliano D, Salamino A, Fogliati MT, Zaffiri O. [Prevention of myalgias caused by succinylcholine with a small dose of a non-depolarizing muscle relaxant]. Minerva Anestesiol. 1981;47(3):73-8.

2. Oxom DC, Whatley GS, Knox JW, Hooper JG. Atracurium and Dtubocurarine pretreatment in the prevention of succinylcholine myalgias: a study in vaginal hysterectomies. Can J Anaesth. 1990;37(4 Pt 2):S140.

3. Abbas N, Tariq S, Khan AW, Murtaza G, Naqvi N, Khanzada A. To asses the effects of rocuronium pretreatment on succinylcholine induced fasciculations and postoperative myalgias. J Pak Med Assoc. 2009;59(12):847-50.

4. Hernandez-Palazon J, Noguera-Velasco J, Falcon-Arana LF, Domenech-Asensi P, Burguillos-Lopez S, Nuno de la Rosa-Carrillo
$\mathrm{V}$. [Precurarization with rocuronium prevents fasciculations and biochemical changes after succinylcholine administration]. Rev Esp Anestesiol Reanim. 2004;51(4):184-9.

5. Fukano N, Suzuki T, Ishikawa K, Mizutani H, Saeki S, Ogawa S. A randomized trial to identify optimal precurarizing dose of rocuronium to avoid precurarization-induced neuromuscular block. J Anesth. 2011;25(2):200-4.

6. Farhat K, Waheed A, Pasha AK, Tariq M. Effects of rocuronium pretreatment on muscle enzyme levels following succinylcholine. Pak J Pharm Sci. 2013;26(5):939-42.

7. Blitt CD, Carlson GL, Rolling GD, Hameroff SR, Otto CW. A comparative evaluation of pretreatment with nondepolarizing neuromuscular blockers prior to the administration of succinylcholine. Anesthesiology.1981;55(6):687-9.

8. Pace NL. Prevention of succinylcholine myalgias: a meta-analysis. Anesth Analg. 1990;70(5):477-83.

9. Sakuraba S, Serita R, Kosugi S, Eriksson LI, Lindahl SG, Takeda J. Pretreatment with magnesium sulphate is associated with less succinylcholine-induced fasciculation and subsequent tracheal intubation-induced hemodynamic changes than precurarization with vecuronium during rapid sequence induction. Acto Anaesthesiol Belg. 2006;57(3):253-7.

10. Eisenkraft JB, Mingus ML, Herlich A, Book WJ, Kopman AF. A defasciculating dose of d-tubocurarine causes resistance to succinylcholine. Can J Anaesth. 1990;37(5):538-42.

11. Fisher DM. Clinical pharmacology of neuromuscular blocking agents. Am J Health Syst Pharm. 1999;56(11 Suppl 1):S4-9.

12. Motamed C, Choquette R, Donati F. Rocuronium prevents succinylcholine-induced fasciculations. Can $J$ Anaesth. 1997;44(12):1262-8.

13. Donati F. Dose inflation when using precurarization. Anesthesiology. 2006;105(1):222-3.

14. Stoelting RK. Serum cholinesterase activity following pancuronium and antagonism with neostigmine or pyridostigmine. Anesthesiology. 1976;45(6):674-8.

15. Stovner J, Oftedal N, Holmboe J. The inhibition of cholinesterases by pancuronium. BrJ Anaesth.1975;47(9):949-54.

16. Motamed C, Kirov K, Combes X, Feiss P, Duvaldestin P. Interaction between mivacurium and pancuronium: impact of the order of administration. Eur J Clin Pharmacol. 2005;61(3):175-7.

17. Motamed C, Kirov K, Lieutaud T, Duvaldestin P. The mechanism of pancuronium potentiation of mivacurium block: use of the isolated-arm technique. Anesth Analg. 2000;91(3):732-5.

18. Motamed C, Menad R, Farinotti R, Kirov K, Combes X, Bouleau $\mathrm{D}$, et al. Potentiation of mivacurium blockade by low dose of pancuronium: a pharmacokinetic study. Anesthesiology. 2003;98(5):1057-62.

19. Baraka A, Wakid N, Noueihed R, Karam H, Bolotova N. Pseudocholinesterase activity and atracurium v. suxamethonium block. $\mathrm{Br} J$ Anaesth. 1986;58 Suppl 1:91S-5S.

20. Bissinger U, Lenz G. [Prolonged neuromuscular blockade. Different antagonistic effects following successive exposure to vecuronium and succinylcholine in a patient with atypical plasma cholinesterase]. Der Anaesthesist. 1994;43(2):82-6.

21. Schreiber JU, Lysakowski C, Fuchs-Buder T, Tramer MR. Prevention of succinylcholine-induced fasciculation and myalgia: a meta-analysis of randomized trials. Anesthesiology. 2005;103(4):87784

22. Brodsky JB, Brock-Utne JG, Samuels SI. Pancuronium pretreatment and post-succinylcholine myalgias. Anesthesiology. 1979;51(3):259-61. 